\title{
Enduring effects of large legumes and phosphorus fertiliser on jarrah forest restoration 15 years after bauxite mining
}

Article

Accepted Version

Creative Commons: Attribution-Noncommercial-No Derivative Works 4.0

Daws, M. I., Grigg, A. H., Tibbett, M. and Standish, R. J. (2019) Enduring effects of large legumes and phosphorus fertiliser on jarrah forest restoration 15 years after bauxite mining. Forest Ecology and Management, 438. pp. 204-214. ISSN 0378-1127 doi:

https://doi.org/10.1016/j.foreco.2019.02.029 Available at https://centaur.reading.ac.uk/82469/

It is advisable to refer to the publisher's version if you intend to cite from the work. See Guidance on citing.

To link to this article DOI: http://dx.doi.org/10.1016/j.foreco.2019.02.029

Publisher: Elsevier

All outputs in CentAUR are protected by Intellectual Property Rights law, including copyright law. Copyright and IPR is retained by the creators or other copyright holders. Terms and conditions for use of this material are defined in the End User Agreement. 


\section{CentAUR}

Central Archive at the University of Reading

Reading's research outputs online 
1 Enduring effects of large legumes and phosphorus fertiliser on jarrah forest restoration 15 years 2 after bauxite mining

3

4

5 Matthew I. Daws ${ }^{\text {ab* }}$, Andrew H. Grigg ${ }^{\mathrm{a}}$, Mark Tibbett ${ }^{\mathrm{b}}$ and Rachel J. Standish ${ }^{\mathrm{c}}$

6

7 aanvironment Department, Alcoa of Australia Ltd, Huntly Mine, PO Box 172, Pinjarra, WA 8 6208, Australia

$9{ }^{\mathrm{b}}$ Centre for Agri-Environmental Research \& Soil Research Centre, School of Agricultural 10 Policy and Development, University of Reading, Berkshire RG6 6AR, UK

$11{ }^{\mathrm{c} E n v i r o n m e n t}$ and Conservation Sciences, Murdoch University, 90 South Street, Murdoch, WA 12

13

$14 *$ *Corresponding author's details

15 Email address: m.i.daws@ reading.ac.uk 


\section{ABSTRACT}

Restoring nutrients lost in the mining process and re-establishing nutrient-cycling are often key goals of mine restoration. One common strategy to facilitate these goals is to seed fastgrowing legumes combined with one application of P-fertiliser to maximise legume growth and increase soil-N. However, the longer term effects of this strategy have received little attention. Here we report the results of a 15-year-old experiment that was established to test the effects of fertiliser-P application and seeding large understorey legumes, both singly and in combination, on jarrah forest restoration after bauxite mining.

Fifteen years after the establishment of this experiment, the majority of the seeded legumes had senesced, with total legume cover having declined significantly compared with results of the same experiment at 5-years-of-age. Yet, despite the legumes having senesced there were still negative effects of both large legumes and P-fertiliser on species richness and abundance of non-leguminous understorey species. These negative effects may be mediated by the persistent effects of legume competition that was evident at 5 years and the accumulation of significant quantities of leaf litter and fine woody debris in the large legume $\times \mathrm{P}$-addition treatments. Compared with the $0 \mathrm{~kg} \mathrm{P} \mathrm{ha}^{-1}$ treatment, application of $20 \mathrm{~kg} \mathrm{P}^{-1}$ significantly increased jarrah tree growth, but there was no additional benefit of $80 \mathrm{~kg} \mathrm{P} \mathrm{ha}^{-1}$. These data suggest that moderation of P-fertiliser and large understorey legumes could maximise understorey cover, tree growth and understorey species richness, and therefore simultaneously address multiple key restoration goals.

Key words: Acacia, competition, fertilizer, nitrogen, rehabilitation 


\section{Introduction}

Mining operations result in the removal of both above-ground vegetation and topsoil, with the topsoil generally being stockpiled (often for a number of years) between mining and rehabilitation. These disturbances result in a significant loss of nutrients and replacing these nutrients is a goal of both mine rehabilitation and restoration (sensu McDonald et al., 2016). Whilst for both rehabilitation and restoration these nutrients are replaced to increase plant productivity and cover, for mine restoration there are additional ecosystem dynamics to consider, including interspecific competition, plant-soil feedbacks and nutrient-cycling, given the focus to restore historic (pre-mining) native ecosystems

Planting or seeding fast-growing legumes has been a key component of restoring productivity and re-establishing nutrient-cycling in many mine restoration (Ward et al., 1990) and reafforestation operations (e.g. Siddique et al., 2008). Planting legumes has the advantage of $\mathrm{N}_{2}$-fixation, potentially increasing soil-N availability to other species such as trees. In addition, fast growing legumes may help to minimise soil erosion of newly rehabilitated (bare) sites (Ward et al., 1990). This strategy has been widely applied in Australia (Langkamp et al., 1979; Todd et al., 2000; Grant et al., 2007; Brady and Noske, 2010) and elsewhere including the United Kingdom (Bradshaw, 1983) and Brazil (Parrotta and Knowles, 1999, 2001). Growth and N-fixation of legumes can be maximised by applying Pfertiliser to low-P soils since legumes are generally $\mathrm{P}-$, but not $\mathrm{N}$-limited. For example, adding the equivalent of $50 \mathrm{~kg} \mathrm{P} \mathrm{ha}^{-1}$ to mined and restored jarrah forest soils increased annual N-fixation by Acacia pulchella from $12 \mathrm{~kg} \mathrm{~N} \mathrm{ha}^{-1}$ to $85 \mathrm{~kg} \mathrm{~N} \mathrm{ha}^{-1}$ (Hingston et al., 1982). Taken together, the available evidence suggests a beneficial role of legumes in restoration projects.

There are, however, a number of potential disadvantages to a restoration strategy based on establishment of leguminous species facilitated by high P-application rates. These include: (1) increased competition due to the rapid growth and dense vegetation that can result (Koch, 1987), (2) an increase in N-responsive weed species (e.g. Nichols and Carpenter, 2006), (3) elevated fuel loads, particularly for fine fuels from both live and senesced legumes (Todd et al., 2000; Grant et al., 2007), and (4) many legumes produce a thick leaf litter layer that can physically retard the establishment of other understorey species (Boyes et al., 2011; le Stradic, 2014). While applying fertiliser, and particularly P, maximises the initial growth of leguminous species, it can also have negative impacts on the re- 
establishing plant community. Elevated P on ancient soils lacking P can favour annual species, including weeds, while negatively affecting slow growing species and those with specialised P-acquisition strategies, such as Proteaceae (Lambers et al., 2008; Shane et al., 2004). For example, in fynbos restoration in South Africa after a simulated mining disturbance, Holmes (2001) found that adding $26 \mathrm{~kg} \mathrm{P} \mathrm{ha}^{-1}$ increased overall plant density and cover. However, this effect was mainly limited to exotic weeds, and P-addition increased the mortality of native Proteaceae. Similarly, Daws et al. (2013) found that for jarrah forest restored after mining, annual species (weeds and natives) were the main beneficiaries of applied P-fertiliser. Furthermore, while the growth and density of native Proteaceae was insensitive to $\mathrm{P}$ application, the overall species richness of native species was reduced at $\mathrm{P}$ application rates greater than $20 \mathrm{~kg} \mathrm{ha}^{-1}$. Overall, these studies highlight the need for more detailed understanding of the combined effects of P-fertiliser and legumes.

In an experimental test of the effects of seeding large understorey legumes combined with P-addition on jarrah forest restoration, Daws et al. (2015) found that five years after restoration both legume seeding and P-addition resulted in significantly higher plant cover, although cover was dominated by large legumes. $\mathrm{P}$ addition also significantly increased the growth of the dominant tree species Eucalyptus marginata (jarrah): seeding legumes had no impact on tree growth. However, by 10-13 years of age jarrah stands in restored forest are, based on stand thinning experiments, more constrained by water- than P-availability (Grigg and Grant, 2009). Consequently, any initial growth benefit for jarrah from P-application might reduce over-time as water availability becomes more limiting. However, this remains to be tested. For non-leguminous understorey species, both cover and density were negatively affected by seeding large legumes and P-addition. However, previous studies in restored jarrah forest indicate that many larger understorey legumes reach their maximum size at around 5-years-of-age (Daws and Koch, 2015), and that beyond this point, many of these legumes senesce (Daws and Koch, 2015; Grant et al., 2007). The longer-term implications of legume senescence for the trajectory of restoration, and particularly community composition, are unknown.

There are two possible outcomes of legume senescence. Firstly, the debris and litter on the soil surface from senescing legumes may further negatively impact small understorey species, due to either an inability to germinate through deep litter (e.g. small seeded ephemerals; Daws et al., 2005), or by plants being physically buried. For example, in quarry restoration in Brazil Le Stradic et al. (2014) indicated that understorey legume shrubs resulted 
107 in a thick litter layer that limited herbaceous species establishment. Secondly, the senescence 108 of these larger species may increase opportunities for recruitment and growth of smaller and 109 slower growing species. These potential longer-term effects of seeding large legumes and P110 addition on assembly trajectories of restored jarrah forest remain to be tested.

111 In this study, we report on a 15-year-old experiment in restored jarrah forest that had a 112 factorial combination of three P-fertiliser addition rates combined with additional seeding of 113 large legume shrubs. We test, approximately 10 years after the onset of legume senescence 114 whether, (1) understorey cover, density and species richness for non-leguminous species are 115 affected by the initial inclusion of large legumes in the seed mix, (2) whether there are 116 persistent effects of initial P-application on community assembly, and (3) whether there are 117 long-term effects of legume seeding and P-application on tree growth. 


\section{Materials and methods}

\subsection{Study site}

Alcoa of Australia Ltd. (hereafter Alcoa) mines and restores ca. 550 ha of forest each year (Koch, 2007a). The experiment described here was established in 2001 within the Alcoa mining lease located within the Darling Range of Southwest Western Australia (32 $35^{\prime} 06^{\prime \prime} \mathrm{S}$, $116^{\circ} 06^{\prime} 44^{\prime \prime}$ E). The climate of the region is Mediterranean with hot, dry summers and cool, wet winters. Annual rainfall is $1,200 \mathrm{~mm}$, the average summer monthly maximum temperature is $28^{\circ} \mathrm{C}$ and the average winter minimum is $5{ }^{\circ} \mathrm{C}$. The overstorey vegetation is dominated by jarrah (Eucalyptus marginata). The understorey consists of shrubs and herbs predominantly in the families Myrtaceae, Proteaceae, Fabaceae, Restionaceae, Orchidaceae, Apiaceae, Liliaceae (sensu lato), Ericaceae, Asteraceae and Cyperaceae.

Mine pits range from 1 to 20 ha in size and are surrounded by intact forest. The aim of Alcoa's restoration is to establish a self-sustaining jarrah forest ecosystem that fulfils premining land uses including nature conservation, recreation, timber production and water catchments. Restoration involves reshaping the mine pit, ripping to alleviate compaction and spreading fresh topsoil (Koch, 2007a). Restored areas receive fresh topsoil sourced from adjacent areas that have been cleared of vegetation in advance of being mined. This restoration practice ensures availability of soil stored seeds such as legumes (Grant et al., 2007), and microorganisms including the rhizobia that form nitrogen-fixing symbioses with native legumes (Jasper, 2007).

Seeds of local plants are spread over the restored mine pits and planting of nursery grown plants occurs for species where seed application is not a viable establishment method (Koch 2007b). A fertiliser mix is applied by helicopter in late winter or early spring after the completion of restoration. In 2001, this mix contained the equivalent of $80 \mathrm{~kg}$ elemental $\mathrm{P}$ ha ${ }^{1}$ and $80 \mathrm{~kg}$ elemental $\mathrm{N} \mathrm{ha}^{-1}$. The mine pits used for the experiment reported here were excluded from this routine fertiliser application.

\subsection{Experimental design}

In March 2001 within each of six newly restored mine pits, a block containing six 40 $\mathrm{m} \times 50 \mathrm{~m}$ plots was established. A factorial design with two factors was used: with and without seeding of 7 large understorey legume species (a combined total of $217 \mathrm{~g} \mathrm{ha}^{-1}$ of Acacia drummondii, A. extensa, A. lateriticola, A. pulchella, A. urophylla, Bossiaea aquifolium and Mirbelia dilatata seeds); and P-fertiliser application, including none, $20 \mathrm{~kg}$ 
elemental $\mathrm{P} \mathrm{ha}{ }^{-1}$ and $80 \mathrm{~kg}$ elemental $\mathrm{P} \mathrm{ha}{ }^{-1}$. Each experimental plot also received a generic seed mix containing seeds of 108 jarrah forest species which was broadcast by hand in March 2001 (see Appendix 1 for individual species seeding rates). This mix included the dominant tree species jarrah. After seeding, $\mathrm{P}$ was applied once as di-ammonium phosphate, and nitrogen (urea) was added once to each plot at an application rate of $80 \mathrm{~kg}$ elemental $\mathrm{N} \mathrm{ha}^{-1}$. Further details of the experimental design are provided in Daws et al. (2015).

Fifteen months after seeding there were, on average, 0.39 more legume seedlings $\mathrm{m}^{-2}$ in the legume seeding treatment (for more details see Daws et al., 2015). Treatments were allocated randomly to the $40 \mathrm{~m} \times 50 \mathrm{~m}$ plots within each block.

\subsection{Botanical monitoring}

Within each experimental plot, a previously selected central $20 \mathrm{~m} \times 20 \mathrm{~m}$ quadrat (Daws et al. 2015) was surveyed for jarrah trees. In December 2015, for all individual jarrah trees $>2 \mathrm{~m}$ in height we recorded diameter at breast height, bark thickness and tree height. Data for multiple stems was recorded if stems were $>1 \mathrm{~cm}$ diameter.

In October 2015, five $4 \mathrm{~m} \times 4 \mathrm{~m}$ quadrats in the four corners and the centre of the 20 $\mathrm{m} \times 20 \mathrm{~m}$ plot (a total of $80 \mathrm{~m}^{2}$ ) were surveyed for shrubs and herbaceous species; the number, identity and percentage cover (a visual estimate that included overhang) of these species was recorded. Estimation of cover took place using frames within the monitoring quadrats, and for each species took into account vertical structuring of the understorey. As a result, it was possible for the sum of all cover estimates to exceed $100 \%$.

\subsection{Leaf litter depth measurements}

Leaf litter depth was measured to assess whether there was increased accumulation of leaf litter when large legumes were included in the seed mix since this is one potential mechanism for large legumes to exhibit an ongoing impact on vegetation composition (hypothesis 1). For three of the six restored mine pits measurements of leaf litter depth were recorded at 45 random locations per plot in February 2016. It was not possible to take measurements of the other three sites due to an intense wild-fire burning these sites in January 2016. Leaf litter depth was also sampled in three $20 \mathrm{~m} \times 20 \mathrm{~m}$ quadrats in non-mined forest. Based on fire history data from the Department of Parks and Wildlife, these sites had not been burnt within the previous 15-year period, i.e. leaf litter had been accumulating for at least the 15-year duration of the current experiment. 


\subsection{Soil nutrient analyses}

Soil samples were analysed for plant available-P to allow an assessment of whether potential long-term impacts of a single initial P application (hypothesis 2) result from greater ongoing availability of soil-P. Soil sampling was planned to take place in January 2016. However, this was delayed to 2018 due to wildfires burning three of the experimental blocks in January 2016 and a further two blocks in 2017. While Ward et al. (1991) reported that wildfire can result in significant losses of $\mathrm{N}$ from jarrah forest soils, they found no effect on the main focus of our present study - soil P. In January 2018, soil samples were collected from the six experimental blocks. Within each of the six plots within each block, six samples were taken from 0 to $10 \mathrm{~cm}$ depth randomly across each plot. All samples were collected from the bottom of the furrows caused by contour ripping at the outset of restoration. The six samples per plot were then bulked to form a composite sample, air dried and passed through a $2 \mathrm{~mm}$ sieve to remove the gravel fraction before being sent to a commercial laboratory for nutrient analyses (CSBP Soil and Plant Laboratories, Bibra Lake, Perth). Total N, ammonium $\left(\mathrm{NH}_{4}{ }^{+}\right)$, total organic carbon and Colwell $\mathrm{P}$ were determined using the methodology of Rayment and Higginson (1992).

\subsection{Statistical analyses}

For analysis of the effects of seeding the seven large legumes (hypothesis 1), and application of phosphorus (hypothesis 2) on species richness, stem density and cover, each plant species was assigned to one of five categories reflecting hypothesised responses to P. We predicted that non-native weeds and ephemerals would respond positively to fertiliser application (Prober and Wiehl, 2012), re-sprouters and Proteaceae would respond negatively (Lambers et al., 2008) and that long-lived re-seeders would be mixed in their responses. Plants were categorised as either: (1) ephemerals (short-lived native species), (2) non-native species (weeds), (3) Proteaceae, (4) re-sprouters or (5) re-seeders (see Appendix 2 for species assignment to the five categories). Following Bell (2001), re-seeders must re-establish through germination and establishment of seedlings, whereas re-sprouters can re-establish by sprouting from surviving underground structures. It should be noted that in Bell's categorisation, used for fire response, ephemerals and weeds are also re-seeders; whereas the re-seeder category used here consisted only of longer-lived species. 
In addition, proteaceous species were all re-sprouters and were therefore excluded

217 from the re-sprouter category. Since the large seeded legumes are all in the re-seeder

218 category, these species were excluded from analyses of the effect of $\mathrm{P}$ and large legumes on

219 re-seeder species. Species were classified as re-sprouters and re-seeders based on published

220 literature (Bellairs and Bell, 1990; Bell et al., 1993; Ward et al., 1997; Smith et al., 2000;

221 Norman et al., 2006a; Burrows et al., 2008). Native ephemerals and weed species were

222 classified based on the FloraBase database (Western Australian Herbarium, 2012).

223 We used MANOVA (implemented in Minitab 16) to assess effects of $\mathrm{P}$ and seeding

224 legumes on percentage cover and the number of species and stems within the various growth

225 form categories. In this analysis, 'Pit' was included as a random factor. For significant terms

226 in the MANOVA model, uni-variate GLMs were used to assess differences among the

227 growth-form categories. In all analyses, the three P-application rates $\left(0,20\right.$ and $\left.80 \mathrm{~kg} \mathrm{ha}^{-1}\right)$

228 were treated as levels of a single treatment and a critical alpha of 0.05 was used to assess

229 significance. 


\section{Results}

\subsection{Soil chemical analyses}

Seventeen years after the establishment of this experiment, there were no effects of either experimental treatment on total soil $\mathrm{N}$, total organic carbon or soil $\mathrm{NH}_{4}{ }^{+}$(Table 1). The addition of P-fertiliser resulted in significantly elevated soil Colwell-P, while legume seeding had no effect on soil-P (Table 1).

\subsection{Accumulation of fine woody debris in response to fertiliser and legume seed addition}

The depth of fine debris and leaf litter increased significantly with both P-application and seeding large legumes (Table 1). This resulted in leaf litter depth being greater than in unmined forest in the legume seeding treatment when either 20 or $80 \mathrm{~kg} \mathrm{P} \mathrm{ha}^{-1}$ were applied (Table 1). There was also a significant $\mathrm{P} \times$ legume interaction indicating that the effect of seeding legumes on litter accumulation was greatest when $\mathrm{P}$ was also applied.

\subsection{Legume responses to fertiliser and legume seed addition}

The inclusion of 7 additional legume species in the seed mix had no significant effect on the total number of legume species present after 15 years (Fig 1A). However, there were significantly fewer legume species present when $\mathrm{P}$ was applied at a rate of $80 \mathrm{~kg} \mathrm{ha}^{-1}$ compared with either 0 or $20 \mathrm{~kg} \mathrm{ha}^{-1}$ : there was at least one fewer species present at $80 \mathrm{~kg} \mathrm{P}$ $\mathrm{ha}^{-1}$ compared with the other application rates (Fig 1A). There was no effect of either seeding large legumes or P-application rate on the density of legumes 15 years after the onset of rehabilitation (Fig 1B). However, total legume cover was significantly increased by the inclusion of large legumes in the seed mix, the addition of $\mathrm{P}$ fertiliser, and the interaction between seeding and fertiliser addition (Fig 1C).

\subsection{Understorey responses to fertiliser and legume seed addition}

The addition of P-fertiliser resulted in a highly significant reduction in the species richness of non-leguminous understorey species (Fig 2AB). For example, in the absence of large legumes species richness decreased from 38.6 species at $0 \mathrm{~kg} \mathrm{ha}^{-1} \mathrm{P}$ to 29.6 species at $80 \mathrm{~kg} \mathrm{ha}^{-1} \mathrm{P}$. Similarly, the addition of large legumes resulted in a significant reduction in non-legume

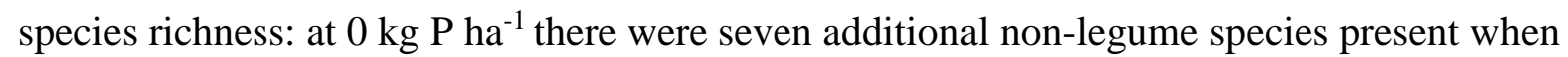
the seven large legumes were not included in the seed mix. In the MANOVA analysis, there was a significant effect of both seeding large legumes and addition of P-fertiliser on the 
distribution of species across the five growth-form categories. Based on univariate tests, phosphorus addition had a significant negative effect on the number of species of re-seeders and a positive effect on the number of weed species. Seeding large legumes had a significant negative effect on the number of re-sprouter and Proteaceous species.

Application of P-fertiliser significantly affected both the density of non-leguminous understorey plants and their distribution across the five growth-form categories (Fig 2CD). For example, in the absence of seeded large legumes, total plant density declined from 2.85 to 2.16 stems $\mathrm{m}^{-2}$ as the $\mathrm{P}$-application rate increased from 0 to $80 \mathrm{~kg} \mathrm{ha}^{-1}$ (Fig 2C). There was no significant effect of legume seeding on plant density. The effect of $\mathrm{P}$ on plant density was driven predominantly by significant reductions in the density of re-sprouter and Proteaceous species.

P-addition resulted in a significant decrease in the understorey cover attributable to non-legume species (Fig 2EF). For example, in the absence of seeding large legumes cover declined from 42.6 to $22.9 \%$ as $\mathrm{P}$ application rates increased from 0 to $80 \mathrm{~kg} \mathrm{ha}^{-1}$. Seeding large legumes had no effect on the distribution of plant cover within the five growth form categories (Fig 2EF). The reduction in cover, in relation to $\mathrm{P}$, was driven primarily by the cover of re-sprouter species declining by approximately $50 \%$ as $\mathrm{P}$ increased (Fig 2EF).

\subsection{Jarrah growth responses to fertiliser and legume seed addition}

Increasing $\mathrm{P}$ from 0 to $20 \mathrm{~kg} \mathrm{ha}^{-1}$ significantly increased growth of jarrah in terms of both stand basal area under bark (BAUB) and tree height. As P increased from 0 to $20 \mathrm{~kg} \mathrm{ha}^{-1}$, BAUB increased from approximately $13 \mathrm{~m}^{2} \mathrm{ha}^{-1}$ to $16 \mathrm{~m}^{2} \mathrm{ha}^{-1}$ (Fig. 3A) and tree height from 9.5 to $11 \mathrm{~m}$ (Fig 3B). At $80 \mathrm{~kg} \mathrm{P} \mathrm{ha}^{-1}$ there was no further benefit for tree growth compared with $20 \mathrm{~kg} \mathrm{ha}^{-1}$. There was no effect of seeding large legumes on either BAUB (Fig 3A) or tree height (Fig 3B).

\section{Discussion}

Fifteen years after the establishment of this experiment, application of P-fertiliser increased the growth of legumes and jarrah trees in restored jarrah forest. Including large legumes in the seed mix also increased the cover attributable to legumes. However, the combination of large legumes and high P-application rates significantly reduced the species richness, density and cover of non-legume understorey species. 
While we found that after 15 years legumes were still a significant component of the total understorey cover, total legume cover was less than at 5-years-of-age (Daws et al., 2015). For example, in the $80 \mathrm{~kg} \mathrm{P} \mathrm{ha}^{-1}$ and legume seeding treatment legume cover was $\sim 50$ $\%$ at 5-years-of-age and had declined to $\sim 18 \%$ by 15 years. This result is consistent with previous studies (Daws and Koch, 2015; Grant et al., 2007), which indicated that from about five years of age onwards, many large understorey legumes senesce. Legume senescence was also evident in the leaf litter depth measurements, which indicate a significant accumulation of fine woody debris and leaf litter on the soil surface related to seeding legumes and applying P. Increased litter depth and masses related to legume senescence have been reported in other P fertilised eucalypt forest restoration schemes (George et al. 2010; Tibbett, 2010; Spain et al., 2015) where greater production of litter compared to native forests is a common phenomenon.

It has been hypothesised that seeding a high density of legumes combined with Papplication may increase $\mathrm{N}$-availability to other species and result in, for example, more rapid tree growth (Palaniappan et al., 1979; Ward and Koch, 1996). However, we found no evidence of any benefit of large legumes to tree growth, total soil $\mathrm{N}$ or to $\mathrm{NH}_{4}{ }^{+}$in restored jarrah forest. While increased growth of Eucalyptus species when in mixed plantings with legumes is commonly observed, it is by no means a ubiquitous feature of mixed species plantings. For example, Forrester et al. (2006) reported that the effect of legumes on Eucalyptus growth can depend on factors including the proportion of legumes in the mix and species selection . Conversely, while also not evident in this study, high densities of large understorey legumes can reduce tree growth in both restored sites and forestry plantations (Turvey et al., 1983; Koch, 1987; Forrester et al., 2011). Taken together, these data suggest that in a restoration context, a strategy that includes legumes to increase $\mathrm{N}$-availability may have unpredictable outcomes.

Our current data suggest, at least for the first 15 years of restoration, there are few benefits of a strategy that includes large understorey legumes. Thus, despite an additional seven species being included in the seed mix in the large legume treatment, even the species richness of legumes was not increased: smaller legume species were potentially outcompeted by the seven larger species. Including the seven large legumes in the seed mix also decreased the species richness of non-legume understorey species, presumably due to increased competition. However, the rapid establishment of plant cover, which may minimise initial 
soil erosion is a potential benefit of seeding large legumes, although for Alcoa's operations, ripping on contour is the primary means of erosion control (Koch 2007a).

In our previous study (Daws et al., 2015), applied-P was still present in the soil and impacting vegetation dynamics 5 years after fertiliser addition. While overall soil P levels have declined in the 12 years between this study and our earlier study (Daws et al., 2015), soil-P was still significantly higher in the applied-P treatments 17 years after a single initial application. Furthermore, these levels of soil $\mathrm{P}$ were still higher than the approx. $2 \mathrm{mg} \mathrm{kg}^{-1} \mathrm{P}$ typically observed in reference jarrah forest soils (Standish et al., 2008). Similarly, soil-P levels in restored jarrah forest, and other post-mining environments can remain elevated for at least 26-years after fertiliser addition (Spain et al., 2006; Banning et al., 2008; Standish et al., 2008; Spain et al., 2015). Indeed, a recent study of forest soil P dynamics in a restored tropical eucalypt forest found ongoing net increases in near-surface concentrations of $\mathrm{P}$ over 26 years, potentially storing up future difference between fertilised restored and native forest systems (Spain et al., 2015). Therefore, while P-addition may have mid- to long-term positive impacts on, for example, legume growth (as shown in this current study), there is a potential for ongoing persistent negative effects on other understorey species.

In earlier studies of this system, elevated P significantly increased the abundance of weeds and ephemerals (Daws et al., 2013, 2015). This effect was less apparent at 15-years-ofage: presumably these species have declined in abundance as the forest canopy has closed. However, there was still a negative effect of applied-P on species richness, abundance and cover attributable to non-leguminous native species. These negative effects potentially result from direct toxicity of applied $\mathrm{P}$ to native species since many species in the jarrah forest (e.g. Proteaceae) have specialised adaptations for P-acquisition in this naturally P-deficient system (Lambers et al., 2008; Shane et al., 2004). However, direct toxicity of applied-P in jarrah forest soils may be tempered by the strong P-binding properties of the iron and aluminium hydroxides that are abundant in these soils (Bolan et al., 1983; Handreck, 1997). Additionally, or alternatively, the reduction in species richness of understorey species may be mediated through increased competition from species that respond vigorously to applied-P such as the larger legumes and establishing jarrah trees: indeed, the negative effects of applied-P were most evident for re-sprouter species (including the Proteaceae), which are generally slow growing (Pate et al., 1990; Bowen, 1991; Bowen and Pate, 1993) and some of which exhibited no growth response to applied fertiliser in other studies (e.g. Daws et al., 
2013). The relative importance of direct P-toxicity and competitive effects for the negative effects of P-addition require further study.

Furthermore, a negative effect of $\mathrm{P}$ on non-leguminous understorey species was evident after 15 years despite an overall reduction in both the density and cover of the highly P-responsive legumes due to senescence. While it is probable that legume senescence will have reduced competition in the understorey, an ongoing negative effect of $\mathrm{P}$ may result from the associated increase in accumulation of fine woody debris and litter from senescing legumes. Accumulation of litter may continue to hinder the recruitment of small seeded species (Daws et al., 2005) even after many of the larger legumes have senesced. In addition, jarrah forest restoration has been reported to generally follow the initial floristics model of succession due to a limited ability for most species to colonise into restored mine pits (Norman et al., 2006b). This means that even if the legumes senesce, colonisation of the restored forest by additional species may be limited.

There were significant benefits of applied-P (20 or $\left.80 \mathrm{~kg} \mathrm{ha}^{-1}\right)$ for tree growth albeit with no difference between 20 and $80 \mathrm{~kg} \mathrm{ha}^{-1}$. Although the response to $\mathrm{P}$ was significant, the magnitude of the difference in growth between 0 and $20 \mathrm{~kg} \mathrm{P} \mathrm{ha}^{-1}$ was substantially less than when the trees were measured at 5-years-of-age (Daws et al., 2015). Thus, in our present study stand basal area and average tree height were only $23 \%$ and $16 \%$ greater at 20 compared with the $0 \mathrm{~kg} \mathrm{P} \mathrm{ha}^{-1}$ treatment. In contrast, at 5-years-of-age there was a $230 \%$ and $170 \%$ difference between 0 and $20 \mathrm{~kg} \mathrm{P} \mathrm{ha}^{-1}$ for basal area and tree height, respectively (Daws et al., 2015). This reduction in the relative benefit of adding P-fertiliser suggests that the benefit of $\mathrm{P}$ application for tree growth may disappear over time, although this suggestion remains to be tested. Nonetheless, this result is consistent with other studies that have shown growth of jarrah to be constrained primarily by water availability primarily rather than Pavailability. For example, studies in both 10-13-year-old rehabilitated jarrah forest and unmined forest have shown no growth response to fertiliser addition unless water availability is increased by thinning the stands (Stoneman et al., 1997; Grigg and Grant, 2009).

A trade-off between productivity and diversity has been observed in a range of ecosystems with nutrient enrichment reducing species richness (e.g. Wheeler and Shaw, 1991; Tilman et al. 2001; Wassen et al., 2005). In addition, for a range of vegetation types, fertiliser addition can increase growth and diversity of non-native weeds and decrease the diversity of native understorey plants in post-mining restoration, e.g. boreal sites in Canada 
401

402

403

404

405

406

407

408

409

410

(Errington and Pinno, 2015) and fynbos in South Africa (Holmes, 2001). Combined with our current data, this suggests that a restoration strategy based on maximising early growth and site productivity may not be optimal for re-establishing diverse understorey communities. In a jarrah forest context, although applied P fertiliser did increase early tree growth this benefit also declined markedly over time. Interestingly, mining and clearing operations prior to mining in the jarrah forest result in the loss of $\sim 20 \mathrm{~kg} \mathrm{P} \mathrm{ha}^{-1}$ (Hingston et al., 1980) and it appears that an application rate close to this value may provide an appropriate balance between restoring lost nutrient capital and maximising native plant species richness.

\section{Acknowledgements}

We thank Cameron Richardson, John Koch, Tim Morald and other Alcoa staff for technical assistance. MID is a former, and AHG a current paid employee of Alcoa of Australia Ltd. This research was funded by Alcoa of Australia Ltd and the Australian Research Council (LP0668931).

\section{References}

Banning, N.C., Grant, C.D., Jones, D.L., Murphy, D.V., 2008. Recovery of soil organic matter, organic matter turnover and nitrogen cycling in a post-mining forest rehabilitation chronosequence. Soil Biol. Biochem. 40, 2021-2031.

Bell, D.T., 2001. Ecological response syndromes in the flora of southwestern Western Australia: fire resprouters versus reseeders. Bot. Rev. 67, 417-440.

Bell, D.T., Plummer, J.A., Taylor, S.K., 1993. Seed germination ecology in southwestern Western Australia. Bot. Rev. 59, 24-73.

Bellairs, S.M., Bell, D.T., 1990. Canopy-borne seed store in three Western Australian plant communities. Aust. J. Ecol. 15, 299-305.

Bolan, N.S., Robson, A.D., Barrow, N.J., 1983. Plant and soil factors including mycorrhizal infection causing sigmoidal response of plants to applied phosphorus. Plant Soil 73, 187201.

Bowen, B.J., 1991. Fire response within the family Proteaceae: A comparison of plants displaying the seeder and resprouter mode of recovery. $\mathrm{PhD}$ thesis, University of Western Australia, Perth, WA, AU. 
Bowen, B.J., Pate, J.S., 1993. The significance of root starch in post-fire shoot recovery of the resprouter Stirlingia latifolia $\mathrm{R}$. Br. (Proteaceae). Ann. Bot. 72,7-16.

Boyes, L.J., Gunton, R.M., Griffiths, M.E., Lawes, M.J., 2011. Causes of arrested succession in coastal dune forest. Plant Ecol. 212, 21-32.

Bradshaw, A.D., 1983. The reconstruction of ecosystems. J. Appl. Ecol. 20, 1-17.

Brady, C.J., Noske, R.A., 2010. Succession in bird and plant communities over a 24-Year chronosequence of mine rehabilitation in the Australian monsoon tropics. Restor. Ecol. 18, $855-864$.

Burrows, N.D., Wardell-Johnson, G., Ward, B., 2008. Post-fire juvenile period of plants in south-west Australia forests and implications for fire management. J.Royal Soc. Western Australia 91, 163-174, Fire response database available at http://naturemap.dec.wa.gov.au

Daws, M.I., Standish, R.J., Koch, J.M., Morald, T.K., Tibbett, M. and Hobbs, R.J. (2015) Phosphorus fertilisation and large legume species affect jarrah forest restoration after bauxite mining. Forest Ecol. Manage. 354, 10-17.

Daws, M.I., Koch, J.M., 2015. Long-term restoration success of re-sprouter understorey species is facilitated by protection from herbivory and a reduction in competition. Plant Ecol. 216, 565-576.

Daws, M.I., Pearson, T.R.H., Burslem, D.F.R.P., Mullins, C.E., Dalling, J.W., 2005. Effects of topographic position, leaf litter and seed size on seedling demography in a semi-deciduous tropical forest in Panama. Plant Ecol. 179, 93-105.

Daws, M.I., Standish, R.J., Koch, J.M., Morald, T.K., 2013. Nitrogen and phosphorus fertiliser regime affect jarrah forest restoration after bauxite mining in Western Australia. Appl. Veg. Sci. 16, 610-618.

Errington, R.C., Pinno, B.D., 2015. Early successional plant community dynamics on a reclaimed oil sands mine in comparison with natural boreal forest communities. Ecoscience $22,133-144$.

Forrester, D.I., Bauhus, J., Cowie, A.L. Vanclaye, J.K., 2006. Mixed-species plantations of Eucalyptus with nitrogen-fixing trees: a review. For Ecol Manage. 233, 211-230.

Forrester, D.I., Vanclay, J.K., Forrester, R.I., 2011. The balance between facilitation and competition in mixtures of Eucalyptus and Acacia as stands develop. Oecologia 166, 265272.

George S.J., Kelly, R.N., Greenwood, P.F., Tibbett, M. (2010). Soil carbon and litter development along a reconstructed biodiverse forest chronosequence of South-Western Australia. Biogeochem. 101, 197-209. 
Grant, C.D., Ward, S.C., Morley, S.C., 2007. Return of ecosystem function to restored bauxite mines in Western Australia. Restor. Ecol. 15, S94-S103.

Grigg A.H., Grant C.D., 2009. Overstorey growth response to thinning, burning and fertiliser in 10-13-year-old rehabilitated jarrah (Eucalyptus marginata) forest after bauxite mining in south-western Australia. Aust. For. 72, 80-86.

Handreck, K.A., 1997. Phosphorus requirements of Australian native plants. Aust. J. Soil Res. $35,241-289$.

Hingston, F.J., Dimmock, G.M., Turton, A.G., 1980. Nutrient distribution in a jarrah (Eucalyptus marginata Donn ex Sm.) ecosystem in south-west Western Australia. For. Ecol. Manage. 3, 183-207.

Hingston, F.J., Malajcsuk, N., Grove, T.S., 1982. Acetylene reduction ( $\mathrm{N}_{2}$-fixation) by jarrah forest legumes following fire and phosphate addition. J. Appl. Ecol. 19,631-645.

Holmes, P.M., 2001. Shrubland restoration following woody alien invasion and mining: effects of topsoil depth, seed source, and fertilizer addition. Restor. Ecol. 9, 71-84.

Jasper, D.A., 2007. Beneficial soil microorganisms of the jarrah forest and their recovery in bauxite mine restoration in southwestern Australia. Restor. Ecol. 15, S74-S84.

Koch, J.M., 1987. Nitrogen accumulation in a rehabilitated bauxite-mined area in the Darling Range, Western Australia. Aust. Forest Res. 17, 59-72.

Koch, J.M., 2007a. Alcoa's mining and restoration process in South Western Australia Restoration Ecology 15, S11-S16.

Koch, J.M., 2007b. Restoring a Jarrah forest understorey vegetation after bauxite mining in Western Australia. Restor. Ecol. S26-S39.

Lambers, H., Raven, J.A., Shaver, G.R., Smith, S.E., 2008. Plant nutrient-acquisition strategies change with soil age. Trends Ecol. Evol. 23, 95-103.

Langkamp, J.P., Swinden, L.B., Dalling, M.J., 1979. Nitrogen fixation by Acacia pellita on areas restored after mining at Groote Eylandt, Northern Territory. Aust. J. Bot. 27, 353-361.

Le Stradic, S., Buisson, E., Negreiros, D., Campagne, P., Fernandes, G.W., 2014. The role of native woody species in the restoration of Campos Rupestres in quarries. Appl. Veg. Sci. 17, 109-120.

McDonald, T., Gann, G.D., Jonson, J., Dixon, K.W. 2016. International standards for the practice of ecological restoration - including principles and key concepts. Society for Ecological Restoration, Washington, D.C.

Nichols, J.D., Carpenter, L., 2006 Interplanting Inga edulis yields nitrogen benefits to Terminalia amazonica. For Ecol Manage. 233, 344-351. 
Norman, M.A., Plummer, J.A., Koch, J.M., Mullins, G.R., 2006a. Optimising smoke treatments for jarrah (Eucalyptus marginata) forest rehabilitation. Aust. J. Bot 54, 571-581.

Norman, M.A., Koch, J.M., Grant, C.D., Morald, T.K., Ward, S.C., 2006b. Vegetation succession after bauxite mining in Western Australia. Restor Ecol 14, 278-288.

Palaniappan, V.M., Marrs, R.H., Bradshaw, A.D., 1979. The effect of Lupinus arboreus on the nitrogen status of china clay wastes. J. Appl. Ecol. 16, 825-831.

Parrotta, J.A., Knowles, O.H., 1999. Restoration of tropical moist forests on bauxite mined lands in the Brazilian Amazon. Restor. Ecol. 7, 103-116.

Parrotta, J.A., Knowles, O.H., 2001. Restoring tropical forests on lands mined for bauxite: examples from the Brazilian Amazon. Ecol. Eng. 17, 219-239.

Pate, J.S., Froend, R.H., Bowen, B.J., Hansen, A., Kuo, J., 1990. Seedling growth and storage characteristics of seeder and resprouter species of Mediterranean-type ecosystems of S.W. Australia. Ann. Bot. 65, 585-601.

Prober, S.M., Wiehl, G., 2012. Relationships among soil fertility, native plant diversity and exotic plant abundance inform restoration of forb-rich eucalypt woodlands. Divers. Distrib. $18,795-807$.

Rayment, G.E., Higginson, F.R., 1992. Australian Laboratory Handbook of Soil and Water Chemical Methods. Inkata Press, Melbourne.

Shane, M.W., Szota, C., Lambers, H., 2004. A root trait accounting for the extreme phosphorus sensitivity of Hakea prostrata (Proteaceae). Plant Cell Environ. 27, 991-1004.

Siddique, I., Lex Engel, V., Parrotta, J.A., Lamb, D., Nardoto, G.B., Ometto, J.P.H.B., Martinelli, L.A., Schmidt, S., 2008. Dominance of legume trees alters nutrient relations in mixed species forest restoration plantings within seven years. Biogeochem. 88, 89-101.

Smith, M.A., Loneragan, W.A., Grant, C.D., Koch, J.M., 2000. Effect of fire on the topsoil seed banks of rehabilitated bauxite mine sites in the jarrah forest of Western Australia. Ecol. Manage. Restor. 1, 50-58.

Spain, A.V., Hinz, D.A., Ludwig, J.A., Tibbett, M., Tongway, D.J., 2006. Mine closure and ecosystem development - Alcan Gove Bauxite Mine, Northern Territory, Australia. In: Fourie, A.B., Tibbett, M. (Eds.), Mine Closure 2006. Australian Centre for Geomechanics, Perth, Western Australia, pp. 299-308.

Spain, A.V., Tibbett, M., Hinz, D.A., Ludwig J.A., Tongway, D.J. 2015. The miningrestoration system and ecosystem development following bauxite mining in a biodiverse environment of the seasonally dry tropics, Northern Territory, Australia. In: Mining in Ecologically Sensitive Landscapes (Ed M. Tibbett), pp. 159-227. CRC Press, Netherlands. 
Standish, R.J., Morald, T.K., Koch, J.M., Hobbs, R.J., Tibbett, M., 2008. Restoring jarrah forest after bauxite mining in Western Australia: the effect of fertiliser on floristic diversity and composition. In: Fourie, A.B., Tibbett, M., Weiersbye, I.M.,Dye, P.J. (Eds.), Mine Closure 2008. Australian Centre for Geomechanics, Perth, Western Australia, pp. 717-725.

Stoneman, G.L., Crombie, D.S., Whitford, K., Hingston, F.J., Giles, R., Portlock, C.C., Galbraith, J.H., Dimmock, G.M., 1997. Growth and water relations of Eucalyptus marginata (jarrah) stands in response to thinning and fertilization. Tree Phys. 16, 267-274.

Tibbett, M., 2010. Large-scale Mine Site Restoration of Australian Eucalypt Forests After Bauxite Mining: Soil Management and Ecosystem Development. In: Ecology of Industrial Pollution L.C. Batty \& K. Hallberg, (Eds), pp. 309-326. Cambridge University Press, UK.

Tilman, D., Reich, P.B., Knops, J., Wedin, D., Mielke, T., Lehman, C., 2001. Diversity and productivity in a long-term grassland experiment. Science 294, 843-845.

Todd, M.V.L., Adams, M.A., Grierson, P.F., 2000. Mineralisation of nitrogen in a chronosequence of rehabilitated bauxite mines. Aust. J. Soil Res. 38, 435-451.

Turvey, N.D., Attiwell, P.M., Cameron, J.N., Smethurst, P.J., 1983. Growth of planted pine trees in response to variation in the densities of naturally regenerated Acacias. For. Ecol. Manage. 7, 103-117.

Ward, S.C., Koch, J.M., 1996. Biomass and nutrient distribution in a 15.5 year old forest growing on a rehabilitated bauxite mine. Aust. J. Ecol. 21, 309-315.

Ward, S.C., Koch, J.M., Ainsworth, G.L., 1991. The effect of controlled burns on nitrogen and phosphorus in rehabilitated bauxite mines. Environmental Department Research Bulletin 18, 1-16, ALCOA of Australia Ltd.

Ward, S.C., Koch, J.M., Grant, C.D., 1997. Ecological aspects of soil seed-banks in relation to bauxite mining. I. Unmined jarrah forest. Aust. J. Ecol. 22, 169-176.

Ward, S.C., Koch, J.M., Nichols, O.G., 1990. Bauxite mine rehabilitation in the Darling Range, Western Australia. Proc. Ecol. Soc. Aust. 16, 557-565.

Wassen, M.J., Venterink, H.O., Lapshina, E.D., Tanneberger, F., 2005. Endangered plants persist under phosphorus limitation. Nature 437, 547-550.

Western Australian Herbarium, 2012. FloraBase - the Western Australian Flora. Department of Environment and Conservation. <http://florabase.dec.wa.gov.au/>.

Wheeler, B.D., Shaw, S.C., 1991. Aboveground crop mass and species richness of the principal types of herbaceous rich-fen vegetation of lowland England and Wales. J. Ecol. 79, 285301. 
555 Table 1. The effects of phosphorus addition and seeding large legumes on the soil properties 556 in the experimental plots in January 2018, 17 years after phosphorus addition and seeding of 557 large legumes in a fully factorial experiment. Also shown is the depth of accumulated leaf 558 litter and fine woody debris measured in 2016, 15 years after establishment of the 559 experiment.

\begin{tabular}{lllllll}
\hline P-application & Large & Total $\mathrm{N}$ & Colwell P & Total & $\mathrm{NH}_{4}-\mathrm{N}$ & Litter layer \\
rate $\left(\mathrm{kg} \mathrm{ha}^{-1}\right)$ & $\begin{array}{l}\text { legumes } \\
\text { seeded? }\end{array}$ & $(\%)$ & $\mathrm{mg} \mathrm{kg}^{-1}$ & organic & $\mathrm{mg} \mathrm{kg}^{-1}$ & depth (mm) \\
& & & & & \\
& & & & &
\end{tabular}

\section{Experimental treatments}

0

20

80
Yes

$0.16 \pm 0.02$

$3.67 \pm 0.33$

$2.53 \pm 0.36$

$0.14 \pm 0.03 \quad 3.67 \pm 0.71$

$2.71 \pm 0.29$

$0.16 \pm 0.01 \quad 4.00 \pm 0.52$

$3.13 \pm 0.36$

$0.14 \pm 0.02$

$4.33 \pm 0.76$

$2.77 \pm 0.34$

$0.19 \pm 0.04 \quad 7.83 \pm 0.83$

$3.70 \pm 0.10$

$0.14 \pm 0.03 \quad 7.00 \pm 0.58$

$2.78 \pm 0.30$

No

$6.17 \pm 0.83$

$29.2 \pm 8.7$

n.d.

n.d.

n.d.

n.d.

$68.1 \pm 7.5$

\section{Unmined forest}

Nil

N/A

ean.

$560 \quad$ Means \pm 1 SE of the mean.

561 n.d. $=$ not determined. 


\section{Figure legends:}

563 Fig. 1. The effects of phosphorus fertiliser application rate and seeding large legumes on: (A)

564 the species richness, (B) the number of individual plants, and (C) total cover of legume

565 species, 15 years after seeding and fertiliser addition. Error bars are $+1 \mathrm{SE}$ of the mean.

566 Fig. 2. The effect of phosphorus application rate and seeding large legumes on, (A, B)

567 established species richness, (C, D) seedling density, and (E, F) plant cover in each of five

568 growth form categories (weeds, native ephemerals, Proteaceae, re-sprouter and re-seeder

569 species). Legume species are excluded from these plots. Note that Proteaceae are hardly

570 visible on $\mathrm{C}$ and $\mathrm{D}$ due to low overall plant densities and that ephemerals and weeds are not

571 visible on $\mathrm{E}$ and $\mathrm{F}$ due to very low overall cover associated with these groups. Error bars are

$572-1$ SE of the mean.

573 Fig. 3. The effect of phosphorus fertiliser application rate and seeding additional large

574 legumes on: (A) the basal area, and (B) height, for the tree species jarrah (Eucalyptus

575 marginata), 15 years after seeding and fertiliser addition. Error bars are +1 SE of the mean. 
Fig. 1

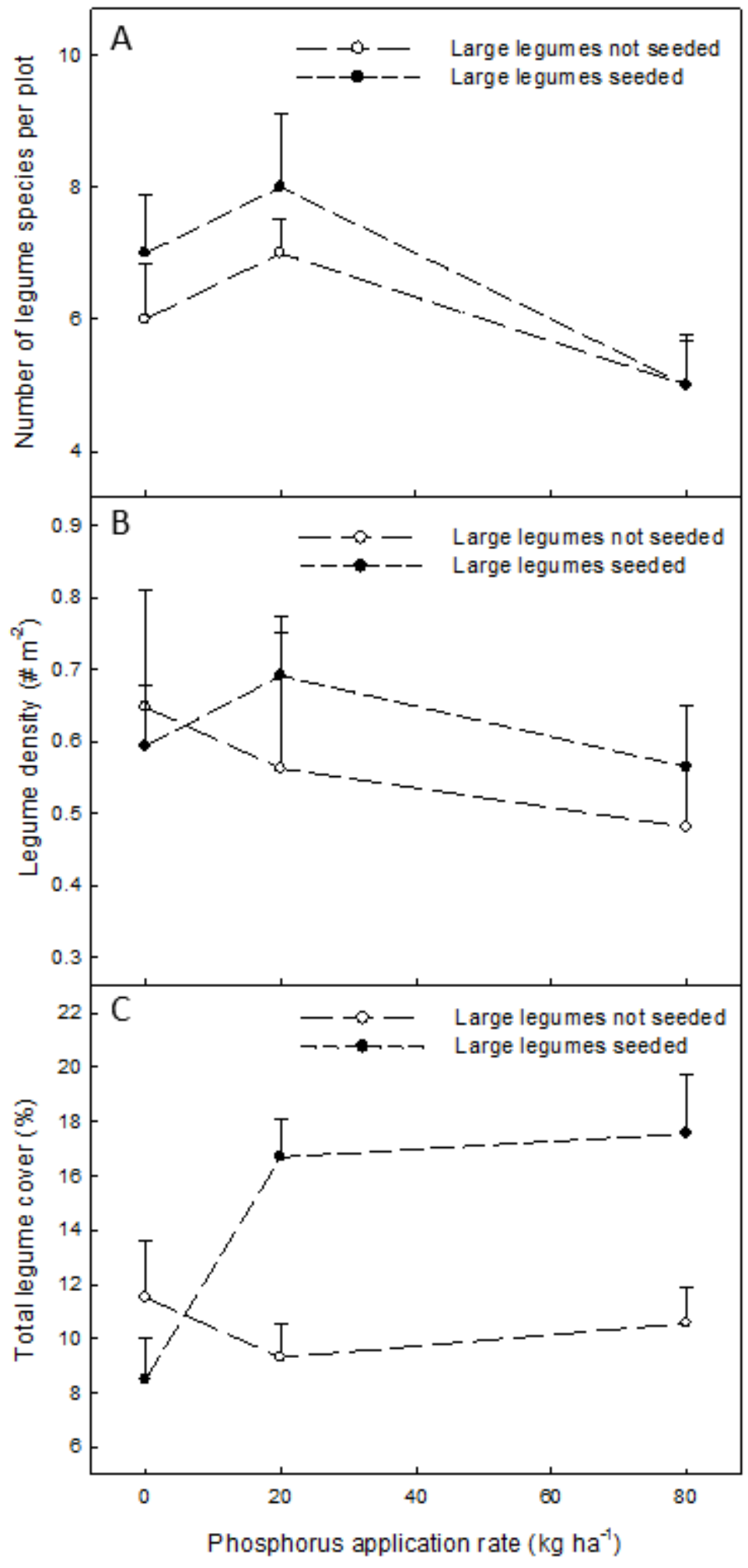


Fig. 2

583
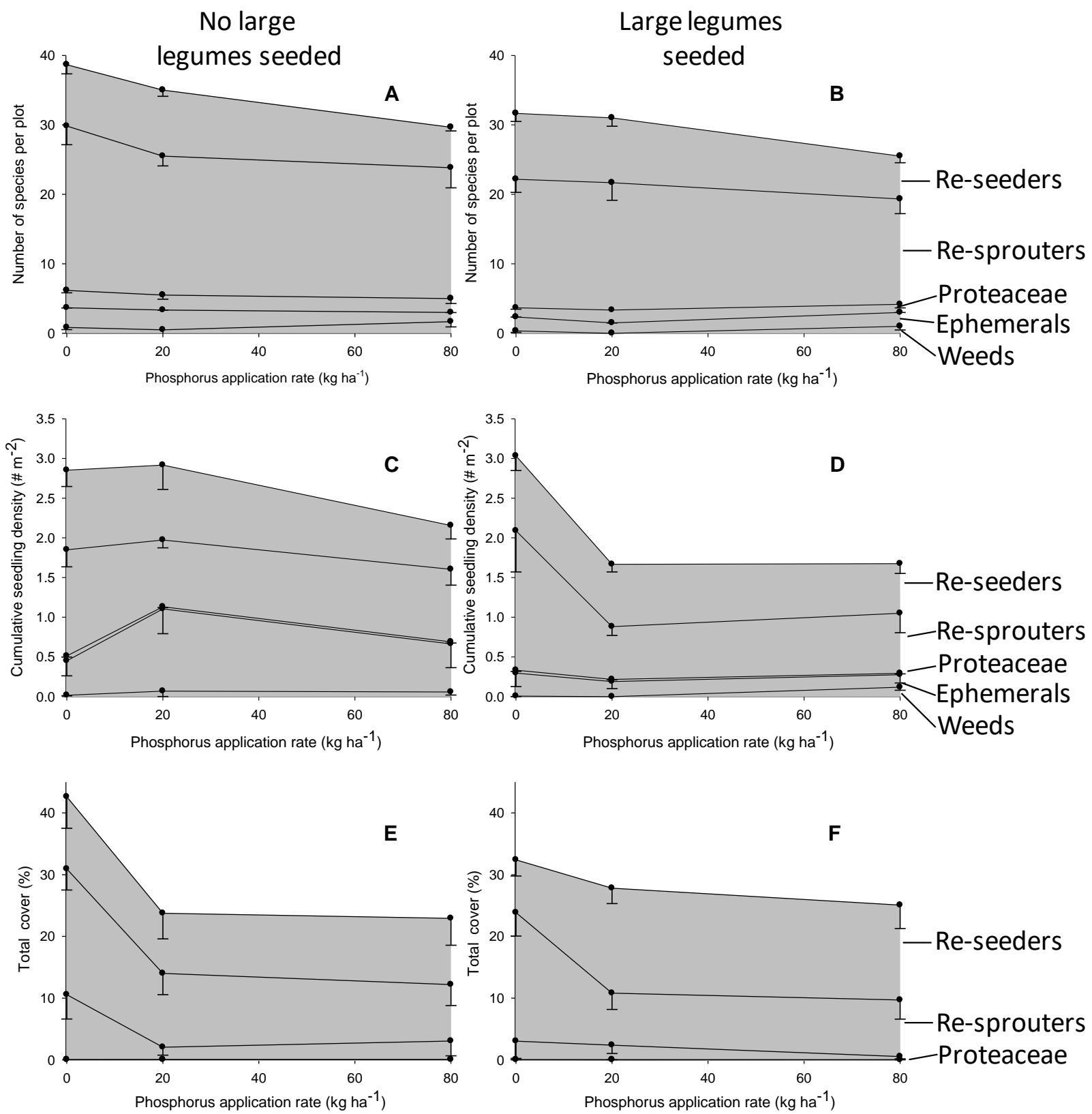
Fig 3.

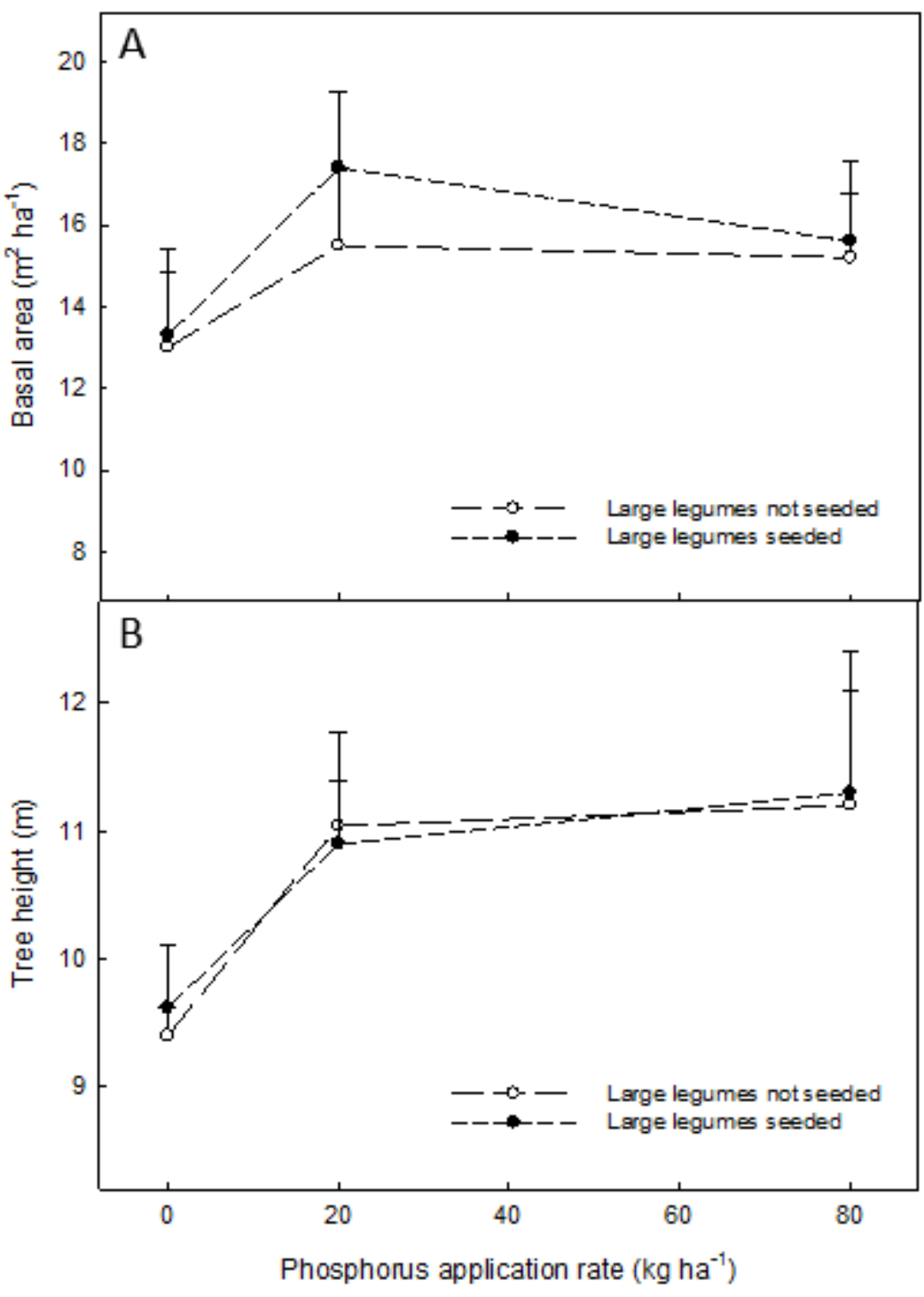

589

590

591

592 
593 Appendix 1: Seeding rates used in the experiment.

\begin{tabular}{|c|c|c|}
\hline Species & Family & $\begin{array}{l}\text { Seed } \\
\text { application } \\
\text { rate }\left(\# \mathrm{ha}^{-1}\right)\end{array}$ \\
\hline Acacia drummondii* & Fabaceae & 15881 \\
\hline Acacia extensa* & Fabaceae & 1791 \\
\hline Acacia horridula & Fabaceae & 114 \\
\hline Acacia lateriticola* & Fabaceae & 5516 \\
\hline Acacia nervosa & Fabaceae & 139 \\
\hline Acacia pulchella* & Fabaceae & 1455 \\
\hline Acacia urophylla* & Fabaceae & 1966 \\
\hline Agrosticrinum scabrum & Anthericaceae & 663 \\
\hline Allocasuaria fraseriana & Casuarinaceae & 736 \\
\hline Amphipogon amphipogonoides & Poaceae & 697 \\
\hline Andersonia involucrata & Epacridaceae & 7896 \\
\hline Andersonia latiflora & Epacridaceae & 11171 \\
\hline Anigozanthos manglesii & Haemodoraceae & 1026 \\
\hline Astroloma ciliata & Epacridaceae & 10 \\
\hline Austrodanthonia caespitosa & Poaceae & 895 \\
\hline Banksia grandis & Proteaceae & 426 \\
\hline Billardiera floribunda & Pittosporaceae & 179 \\
\hline Billardiera fraseri & Pittosporaceae & 33 \\
\hline Billardiera heterophylla & Pittosporaceae & 571 \\
\hline Billardiera variifolia & Pittosporaceae & 145 \\
\hline Boronia fastigiatus & Rutaceae & 216 \\
\hline Bossiaea aquifolium* & Fabaceae & 5111 \\
\hline Bossiaea ornata & Fabaceae & 13844 \\
\hline Burchardia congesta & Colchicaceae & 1967 \\
\hline Chamaescilla corymbosa & Anthericaceae & 298 \\
\hline Chorizema dicksonii & Fabaceae & 1258 \\
\hline Chorizema ilicifolium & Fabaceae & 2884 \\
\hline Clematis pubescens & Ranunculaceae & 96 \\
\hline Conostylis aculeata & Haemodoraceae & 767 \\
\hline Corymbia calophylla & Myrtaceae & 3169 \\
\hline Craspedia variabilis & Asteraceae & 23 \\
\hline Cryptandra arbutiflora & Rhamnaceae & 99 \\
\hline Cyathochaeta avenecea & Cyperaceae & 1312 \\
\hline Daviesia cordata & Fabaceae & 523 \\
\hline Daviesia decurrens & Fabaceae & 37 \\
\hline Daviesia physodes & Fabaceae & 13 \\
\hline Daviesia preissii & Fabaceae & 11 \\
\hline
\end{tabular}




\begin{tabular}{|c|c|c|}
\hline Dianella revoluta & Phormiaceae & 198 \\
\hline Dryandra lindleyana & Proteaceae & 7 \\
\hline Dryandra sessilis & Proteaceae & 1 \\
\hline Eryngium pinnatifidum & Apiaceae & 1082 \\
\hline Eucalyptus marginata & Myrtaceae & 49645 \\
\hline Glischrocaryon aureum & Haloragaceae & 257 \\
\hline Gompholobium knightianum & Fabaceae & 2417 \\
\hline Gompholobium marginatum & Fabaceae & 5693 \\
\hline Gompholobium polymorphum & Fabaceae & 181 \\
\hline Gompholobium preisii & Fabaceae & 378 \\
\hline Gonocarpus cordiger & Haloragaceae & 50 \\
\hline Grevillea pilulifera & Proteaceae & 7 \\
\hline Grevillea quercifolia & Proteaceae & 7 \\
\hline Grevillea wilsonii & Proteaceae & 10 \\
\hline Haemodorum paniculatum & Haemodoraceae & 5 \\
\hline Haemodorum spicata & Haemodoraceae & 76 \\
\hline Hakea amplexicauis & Proteaceae & 40 \\
\hline Hakea cyclocarpa & Proteaceae & 21 \\
\hline Hakea lissocarpa & Proteaceae & 78 \\
\hline Hakea ruscifolia & Proteaceae & 2 \\
\hline Hakea stenocarpa & Proteaceae & 9 \\
\hline Hakea undulata & Proteaceae & 96 \\
\hline Hemigenia rigidum & Labiaceae & 802 \\
\hline Hemigenia sericea & Labiaceae & 170 \\
\hline Hibbertia commutata & Dilleniaceae & 263 \\
\hline Hibbertia huegelii & Dilleniaceae & 196 \\
\hline Hovea chorizemifolia & Fabaceae & 50 \\
\hline Hovea trisperma & Fabaceae & 166 \\
\hline Hyalosperma cotula & Asteraceae & 745 \\
\hline Hybanthus calycinus & Violaceae & 39 \\
\hline Hybanthus floribunda & Violaceae & 14 \\
\hline Hypocalymma angustifolium & Myrtaceae & 4223 \\
\hline Isotoma hypocrateriformis & Campanulaceae & 1768 \\
\hline Kennedia coccinea & Fabaceae & 92 \\
\hline Labichea punctata & Fabaceae & 876 \\
\hline Lagenophora huegelii & Asteraceae & 3401 \\
\hline Lechenaultia biloba & Goodeniaceae & 819 \\
\hline Leucopogon propinquus & Epacridaceae & 54 \\
\hline Leucopogon verticillatus & Epacridaceae & 146 \\
\hline Lomandra nigricans & Dasypogonaceae & 16 \\
\hline Lomandra preissii & Dasypogonaceae & 0.47 \\
\hline Lomandra purpurea & Dasypogonaceae & 39 \\
\hline
\end{tabular}




\begin{tabular}{|c|c|c|}
\hline Lomandra sonderi & Dasypogonaceae & 39 \\
\hline Macrozamia reidlii & Zamiaceae & 155 \\
\hline Marianthus bicolor & Pittosporaceae & 191 \\
\hline Mirbelia dilatata* & Fabaceae & 1442 \\
\hline Neurachne alopecuroidea & Poaceae & 10974 \\
\hline Orthosanthus laxus & Iridaceae & 85 \\
\hline Persoonia elliptica & Proteaceae & 1 \\
\hline Persoonia longifolia & Proteaceae & 1 \\
\hline Phyllanthus calycinus & Euphorbiaceae & 2085 \\
\hline Pimelia ciliata & Thymelaceae & 320 \\
\hline Pimelia suaveolens & Thymelaceae & 47 \\
\hline Ptilotheca spicata & Rutaceae & 29 \\
\hline Ptilotus manglessii & Ameranthaceae & 396 \\
\hline Stackhousia pubescens & Celastraceae & 62 \\
\hline Stylidium amoenum & Stylidiaceae & 7934 \\
\hline Stylidium calcaratum & Stylidiaceae & 5408 \\
\hline Stylidium diuroides & Stylidiaceae & 5408 \\
\hline Stylidium junceum & Stylidiaceae & 453 \\
\hline Stylidium schoenoides & Stylidiaceae & 133 \\
\hline Tetrarrhena laevis & Poaceae & 1536 \\
\hline Tetratheca hirsuta & Tremandraceae & 317 \\
\hline Thysanotus multiflorus & Anthericaceae & 261 \\
\hline Trichocline spathulata & Asteraceae & 62 \\
\hline Tricoryne elatior & Anthericaceae & 65 \\
\hline Tripterococcus brunonis & Celastraceae & 1214 \\
\hline Trymalium ledifolium & Rhamnaceae & 1955 \\
\hline Velleia trinervis & Goodeniaceae & 784 \\
\hline Xanthorrhoea gracilis & Xanthorrhoeaceae & 2415 \\
\hline Xanthorrhoea preissii & Xanthorrhoeaceae & 529 \\
\hline
\end{tabular}


596 Appendix 2: Species recorded in the experiment, and the growth form they were assigned in 597 analyses.

\begin{tabular}{|c|c|c|}
\hline Species & Family & Growth form \\
\hline Acacia drummondii & Fabaceae & Re-seeder \\
\hline Acacia extensa & Fabaceae & Re-seeder \\
\hline Acacia lateriticola & Fabaceae & Re-seeder \\
\hline Acacia pulchella & Fabaceae & Re-seeder \\
\hline Acacia saligna & Fabaceae & Re-seeder \\
\hline Acacia urophylla & Fabaceae & Re-seeder \\
\hline Adenanthos barbiger & Proteaceae* & Re-sprouter \\
\hline Aira caryophyllea & Poaceae & Non-native weed \\
\hline Allocasuarina fraseriana & Casuarinaceae & Re-sprouter \\
\hline $\begin{array}{l}\text { Amphipogon } \\
\text { amphipogonoides }\end{array}$ & Poaceae & Re-sprouter \\
\hline Andersonia lehmanniana & Epacridaceae & Re-seeder \\
\hline Austrodanthonia caespitosa & Poaceae & Re-sprouter \\
\hline Banksia grandis & Proteaceae* & Re-sprouter \\
\hline Billardiera heterophylla & Pittosporaceae & Re-sprouter \\
\hline Boronia fastigiatus & Rutaceae & Re-sprouter \\
\hline Bossiaea aquifolium & Fabaceae & Re-seeder \\
\hline Bossiaea ornata & Fabaceae & Re-sprouter \\
\hline Burchardia congesta & Colchicaceae & Re-sprouter \\
\hline Caladenia flava & Orchidaceae & Re-sprouter \\
\hline Chamaescilla corymbosa & Anthericaceae & Re-sprouter \\
\hline Chorizema cordatum & Fabaceae & Re-sprouter \\
\hline Chorizema dicksonii & Fabaceae & Re-sprouter \\
\hline Chorizema ilicifolium & Fabaceae & Re-sprouter \\
\hline Comesperma calymega & Polygalaceae & Ephemeral \\
\hline Comesperma virgatum & Polygalaceae & Re-sprouter \\
\hline Conostylis serrulata & Haemodoraceae & Re-sprouter \\
\hline Conostylis setigera & Haemodoraceae & Re-sprouter \\
\hline Conostylis setosa & Haemodoraceae & Re-sprouter \\
\hline Conyza bonariensis & Asteraceae & Non-native weed \\
\hline Corymbia calophylla & Myrtaceae & Re-sprouter \\
\hline Cyathochaeta avenacea & Cyperaceae & Re-sprouter \\
\hline Daviesia decurrens & Fabaceae & Re-sprouter \\
\hline Dianella revoluta & Phormiaceae & Re-sprouter \\
\hline Disa bracteata & Orchidaceae & Non-native weed \\
\hline Diuris longifolia & Orchidaceae & Re-sprouter \\
\hline Drosera stolonifera & Droseraceae & Re-sprouter \\
\hline Eucalyptus maculata & Myrtaceae & Re-sprouter \\
\hline Eucalyptus marginata & Myrtaceae & Re-sprouter \\
\hline Gastrolobium spinosum & Fabaceae & Re-sprouter \\
\hline Gompholobium knightianum & Fabaceae & Re-seeder \\
\hline Gompholobium marginatum & Fabaceae & Re-seeder \\
\hline
\end{tabular}




\begin{tabular}{|c|c|c|}
\hline Gompholobium polymorphum & Fabaceae & Re-seeder \\
\hline Gompholobium preissii & Fabaceae & Re-seeder \\
\hline Hakea amplexicaulis & Proteaceae* & Re-sprouter \\
\hline Hakea lissocarpha & Proteaceae* & Re-sprouter \\
\hline Hakea prostrata & Proteaceae* & Re-sprouter \\
\hline Hakea ruscifolia & Proteaceae* & Re-sprouter \\
\hline Hakea stenocarpa & Proteaceae* & Re-sprouter \\
\hline Hakea undulata & Proteaceae* & Re-sprouter \\
\hline Hardenbergia comptoniana & Fabaceae & Re-sprouter \\
\hline Hemigenia rigida & Lamiaceae & Re-seeder \\
\hline Hibbertia acerosa & Dilleniaceae & Re-sprouter \\
\hline Hibbertia amplexicaulis & Dilleniaceae & Re-sprouter \\
\hline Hibbertia commutata & Dilleniaceae & Re-sprouter \\
\hline Hibbertia quadricolor & Dilleniaceae & Re-sprouter \\
\hline Hovea chorizemifolia & Fabaceae & Re-sprouter \\
\hline Hovea trisperma & Fabaceae & Re-sprouter \\
\hline Hybanthus calycinus & Violaceae & Re-sprouter \\
\hline Hybanthus floribundus & Violaceae & Re-sprouter \\
\hline Hypocalymma angustifolium & Myrtaceae & Re-sprouter \\
\hline Hypocalymma cordifolium & Myrtaceae & Re-sprouter \\
\hline Hypochaeris glabra & Asteraceae & Non-native weed \\
\hline Hypolaena exsulca & Restionaceae & Re-sprouter \\
\hline Kennedia coccinea & Fabaceae & Re-seeder \\
\hline Labichea punctata & Fabaceae & Re-sprouter \\
\hline Lagenophora huegelii & Asteraceae & Re-sprouter \\
\hline Lasiopetalum floribundum & Sterculiaceae & Re-sprouter \\
\hline Lepidosperma gracile & Cyperaceae & Re-sprouter \\
\hline Lepidosperma squamatum & Cyperaceae & Re-sprouter \\
\hline Lepidosperma tenue & Cyperaceae & Re-sprouter \\
\hline Leucopogon nutans & Epacridaceae & Re-seeder \\
\hline Leucopogon propinquus & Epacridaceae & Re-sprouter \\
\hline Leucopogon verticillatus & Epacridaceae & Re-sprouter \\
\hline Levenhookia pusilla & Stylidiaceae & Ephemeral \\
\hline Lomandra caespitosa & Dasypogonaceae & Re-sprouter \\
\hline Lomandra drummondii & Dasypogonaceae & Re-sprouter \\
\hline Lomandra hermaphrodita & Dasypogonaceae & Re-sprouter \\
\hline Lomandra preissii & Dasypogonaceae & Re-sprouter \\
\hline Lomandra sericea & Dasypogonaceae & Re-sprouter \\
\hline Lomandra sonderi & Dasypogonaceae & Re-sprouter \\
\hline Lomandra spartea & Dasypogonaceae & Re-sprouter \\
\hline Macrozamia riedlei & Zamiaceae & Re-sprouter \\
\hline Microtis media & Orchidaceae & Re-sprouter \\
\hline Millotia tenuifolia & Asteraceae & Ephemeral \\
\hline Mirbelia dilatata & Fabaceae & Re-seeder \\
\hline Neurachne alopecuroidea & Poaceae & Re-sprouter \\
\hline Opercularia apiciflora & Rubiaceae & Re-seeder \\
\hline
\end{tabular}




\begin{tabular}{|c|c|c|}
\hline Opercularia echinocephala & Rubiaceae & Re-seeder \\
\hline Orthrosanthus laxus & Iridaceae & Re-sprouter \\
\hline Patersonia rudis & Iridaceae & Re-sprouter \\
\hline Pentapeltis peltigera & Apiaceae & Re-sprouter \\
\hline Persoonia longifolia & Proteaceae* & Re-sprouter \\
\hline Phyllanthus calycinus & Euphorbiaceae & Re-sprouter \\
\hline Platysace compressa & Apiaceae & Re-sprouter \\
\hline Platysace tenuissima & Apiaceae & Ephemeral \\
\hline Podolepis gracilis & Asteraceae & Ephemeral \\
\hline $\begin{array}{l}\text { Pseudognaphalium luteo- } \\
\text { album }\end{array}$ & Asteraceae & Non-native weed \\
\hline Pterochaeta paniculata & Asteraceae & Ephemeral \\
\hline Pterostylis pyramidalis & Orchidaceae & Re-sprouter \\
\hline Ranunculus colonorum & Ranunculaceae & Re-sprouter \\
\hline Rhodanthe citrina & Asteraceae & Ephemeral \\
\hline Scaevola calliptera & Goodeniaceae & Re-sprouter \\
\hline Senecio diaschides & Asteraceae & Non-native weed \\
\hline Senecio hispidulus & Asteraceae & Ephemeral \\
\hline Senecio quadridentatus & Asteraceae & Ephemeral \\
\hline Sonchus oleraceus & Asteraceae & Non-native weed \\
\hline Sphaerolobium medium & Fabaceae & Re-sprouter \\
\hline Stylidium amoenum & Stylidiaceae & Ephemeral \\
\hline Stylidium calcaratum & Stylidiaceae & Ephemeral \\
\hline Stylidium hispidum & Stylidiaceae & Ephemeral \\
\hline Stylidium junceum & Stylidiaceae & Ephemeral \\
\hline Styphelia tenuiflora & Epacridaceae & Re-sprouter \\
\hline Tetraria capillaris & Cyperaceae & Re-sprouter \\
\hline Tetrarrhena laevis & Poaceae & Re-sprouter \\
\hline Tetratheca hirsuta & Tremandraceae & Re-sprouter \\
\hline Thelymitra macrophylla & Orchidaceae & Re-sprouter \\
\hline Thysanotus fastigiatus & Anthericaceae & Re-sprouter \\
\hline Thysanotus multiflorus & Anthericaceae & Re-seeder \\
\hline Thysanotus thyrsoideus & Anthericaceae & Re-sprouter \\
\hline Trachymene pilosa & Apiaceae & Ephemeral \\
\hline Trymalium ledifolium & Rhamnaceae & Re-seeder \\
\hline Velleia trinervis & Goodeniaceae & Ephemeral \\
\hline Vellereophyton dealbatum & Asteraceae & Non-native weed \\
\hline Viminaria juncea & Fabaceae & Re-seeder \\
\hline Xanthorrhoea gracilis & Xanthorrhoeaceae & Re-sprouter \\
\hline Xanthorrhoea preissii & Xanthorrhoeaceae & Re-sprouter \\
\hline Xanthosia atkinsoniana & Apiaceae & Re-seeder \\
\hline Xanthosia candida & Apiaceae & Re-seeder \\
\hline Xanthosia huegelii & Apiaceae & Re-seeder \\
\hline
\end{tabular}

